\title{
WIDTH FEEDING STRIPLINE OPTIMISE OF CURVED MiCrostripline ARray VARIANS ANTENNA IN MULTIBAND FREQUENCY FOR RADAR COMMUNICATIONS
}

\author{
Putu Artawan ${ }^{1}$, Josaphat T. Sri Sumantyo ${ }^{2}$, Mashuri ${ }^{1}$ and Yono Hadi Pramono ${ }^{1}$ \\ ${ }^{1}$ Physics Department, Faculty of Natural Sciences, Institut Teknologi Sepuluh Nopember \\ (ITS), Surabaya, Indonesia \\ ${ }^{2}$ Josaphat Microwave Remote Sensing Laboratory, Center for Environmental Remote \\ Sensing (CEReS) Chiba University, 1-33 Yayoi-cho, Inage-ku, Chiba 263-8522-Japan
}

\begin{abstract}
This study proposed to design of curved microstripline array antenna with more optimal characteristics parametric through optimise in width feeding stripline and its application for radar communications. Numeric analysis with an empirical formula in curved microstripline array antenna supports the counting in relation to the characteristics antenna that is optimally applied in communications. The simulations was created by using CST software. The result of simulation is to indicate Voltage Standing Wave Ratio (VSWR), Reflection coefficient, Return Loss and Gain with Vertical Linear Polarization. The optimise of curved microstripline array varians with the varians array and optimise varians in width of the feeding stripline. Based on this simulated result, curved microstripline array varians antenna is potential to developed antenna in radar communication in multiband frequency.
\end{abstract}

\section{KEYWORDS}

Simulation, Curved Microstripline, Multi Band Frequency, Radar Communication

\section{INTRODUCTION}

To design and analyze the shape and size of the antenna required special knowledge regarding the electromagnetic field theory. Electromagnetic fields generated depend on the distance of the source access and terrain [2]. The further course of electromagnetic fields produced less meaning in the spread process electromagnetic waves from the transmitter to the receiver experiencing attenuation (weakening) signals. Therefore, the required antenna design with specific dimensions that have a high gain value and high directivity with return loss is very small [3]. Various studies have been conducted on microstrip antenna $[1,7,8,9,12,17]$. In this research proposed new type of antenna that will be designed to have the characteristics in question are Curved Microstripline Array Antenna Design. This antenna is an antenna type Microstrip with the characteristics of a thin cross section, the mass that is lightweight, easy to make, can be easily integrated with Microwave Integrated Circuits (MICs) and can be made to multifrequency [4,5,6]. In this research, Novel curved microstripline array antenna design and its optimise is propose to develope in Multiband frequency for radar communications. The optimise in width feeding stripline will be done to get optimal result in antenna parametric that as a good performance indicator in multiband frequencies for radar communication application. The proposed Novel curved microstripline array antenna is afford to 
operate in Multiband frequency. The target of Novel curved microstripline array antenna is in multiband frequency, reflection coefficient less than $-10 \mathrm{~dB}$, Voltage Standing Wave Ratio (VSWR) less than 2, gain more than $5 \mathrm{~dB}$, respectively.

\section{EMPIRICAl ANALYSIS AND Design}

The first calculating is to find the total electricity permittivity $\left(\varepsilon_{\text {rtot }}\right)$ using the capacitor equation:

$$
\begin{gathered}
\frac{1}{\mathrm{c}_{\text {tot }}}=\frac{1}{\mathrm{c}_{1}}+\frac{1}{\mathrm{c}_{2}} \\
\frac{1}{\varepsilon_{o} \varepsilon_{r_{\text {tot }}} A / d_{\text {tot }}}=\frac{1}{\varepsilon_{o} \varepsilon_{r_{1}} A_{1} / d_{1}}+\frac{1}{\varepsilon_{o} \varepsilon_{r_{2}} A_{2} / d_{2}}
\end{gathered}
$$

where $\varepsilon_{\mathrm{r} 1}$ is $\varepsilon_{\mathrm{r}}$ for air $\left(\varepsilon_{\mathrm{r} 1}=1\right), \varepsilon_{\mathrm{r} 2}$ is $\varepsilon_{\mathrm{r}}$ for substrate $\left(\varepsilon_{\mathrm{rFR}}=4.3\right), \mathrm{d}_{1}$ thick of substrate and $\mathrm{d}_{2}$ distance of substrate to the reflector, with dtot is $\mathrm{d}_{1}+\mathrm{d}_{2}$.

And then using the following equation:

$$
\varepsilon_{\text {eff }}=\frac{\varepsilon_{r}+1}{2}+\frac{\varepsilon_{r}-1}{2}\left(1+10 \frac{\mathrm{h}}{\mathrm{w}}\right)^{-0,555}
$$

To calculate the effective permittivity electricity ( $\left.\varepsilon_{\text {eff }}\right)$. Where $\varepsilon_{\mathrm{r}}$ is the same with $\varepsilon \mathrm{r}_{\mathrm{tot}}, \mathrm{h}$ is $\mathrm{d}_{\mathrm{tot}}$ and $\mathrm{w}$ is the various wide for patch and stripline side.

The following equation is to know the maximum dimension in the patch side $\left(\mathrm{w}_{1}\right)$ :

$$
\begin{aligned}
\mathrm{f} & =\frac{2 \mathrm{c}}{3 \mathrm{w} \sqrt{\varepsilon_{r}}} \\
w_{1} & =\frac{2 \mathrm{c}}{3 \sqrt{\varepsilon_{r}} \mathrm{f}}
\end{aligned}
$$

where $\mathrm{c}$ is lightspeed in air, $\varepsilon_{\mathrm{r}}$ is electricity permittivity and $\mathrm{f}$ is frequency.

And to calculate the effective width stripline side $\left(\mathrm{w}_{2,3}\right)$, using the following figure:

$$
\mathrm{W}_{2,3}=\frac{1}{2 \mathrm{f} \sqrt{\mu_{0} \cdot Z_{o}}} \sqrt{\frac{2}{\varepsilon_{r}+1}}
$$

Where $\mathrm{f}$ is frequency, $\mu \mathrm{o}$ is permeability constant and $\mathrm{Zo}$ is characteristic impedance.

The calculation wavelength of the substrate ( $\lambda \mathrm{g})$, using the following equation:

$$
\lambda g=\frac{\lambda}{\sqrt{\varepsilon_{e f f}}}
$$

From the analysis above we find to fix the parameter of antenna fabrication.

The following figure is the Curved Microstripline Antenna Design in array varians. 


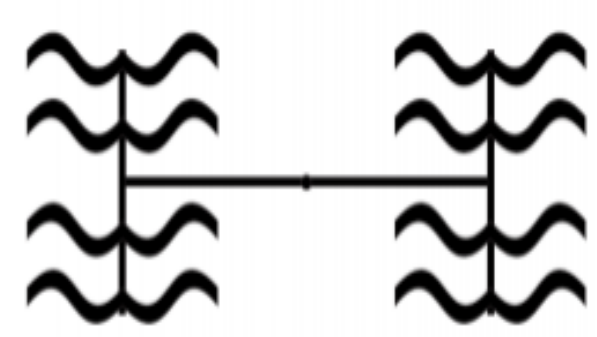

a

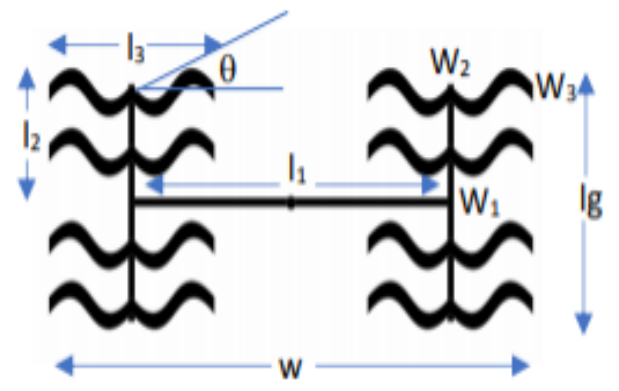

b

Figure 4. (a) Curved Microstripline 2x2 Array Antenna Design

(b) Dimension of Curved Microstripline 2x2 Array Antenna Design

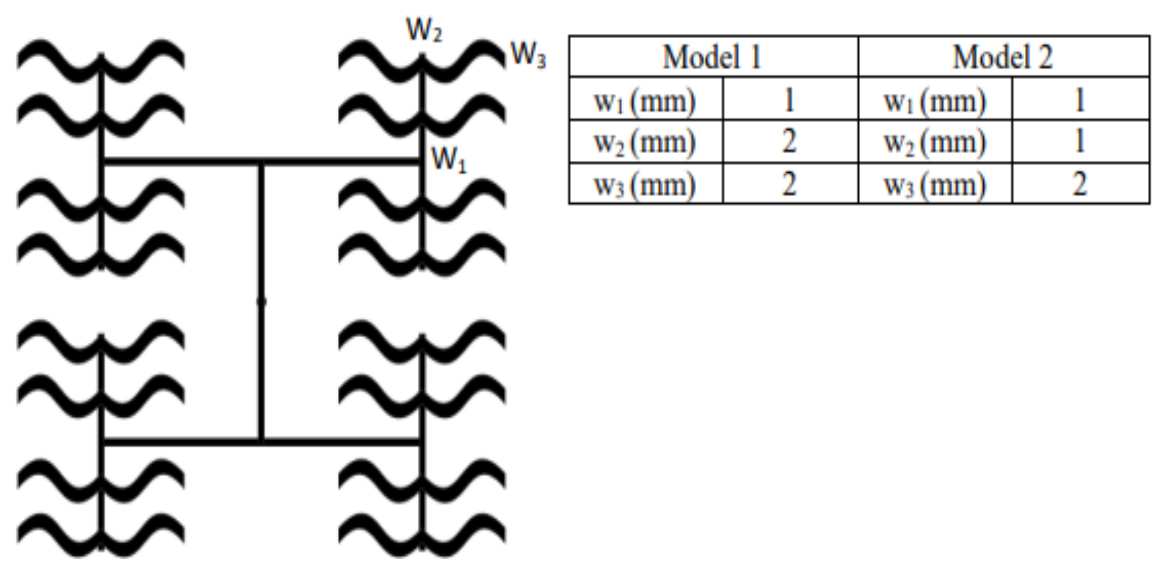

Figure 5. Model 1 and 2 width feeding stripline varians

(Curved Microstripline 2x4 Array Antenna Design)

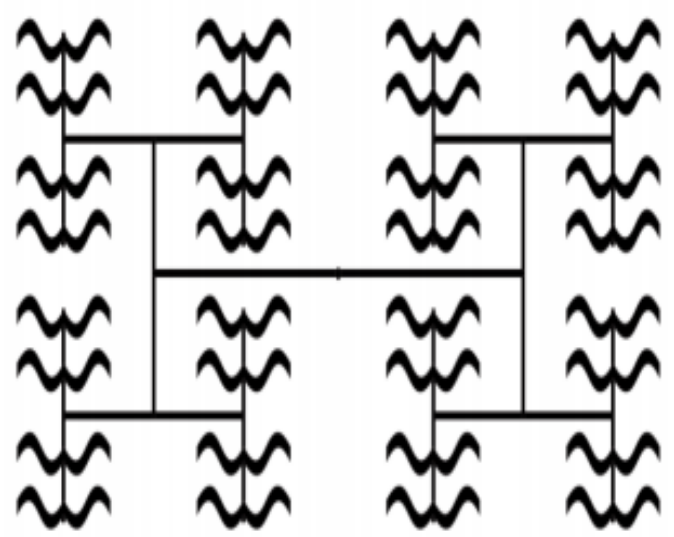

\begin{tabular}{|c|c|c|c|}
\hline \multicolumn{2}{|c|}{ Model 1 } & \multicolumn{2}{c|}{ Model 2} \\
\hline $\mathrm{w}_{1}(\mathrm{~mm})$ & 1 & $\mathrm{w}_{1}(\mathrm{~mm})$ & 1 \\
\hline $\mathrm{w}_{2}(\mathrm{~mm})$ & 2 & $\mathrm{w}_{2}(\mathrm{~mm})$ & 1 \\
\hline $\mathrm{w}_{3}(\mathrm{~mm})$ & 2 & $\mathrm{w}_{3}(\mathrm{~mm})$ & 2 \\
\hline
\end{tabular}

Figure 6. Model 1 and 2 width feeding stripline varians

(Curved Microstripline 4x4 Array Antenna Design) 
International Journal of Wireless \& Mobile Networks (IJWMN) Vol. 11, No.2, April 2019

\section{RESULT AND DISCUSSION}

The simulation result of Curved Microstripline 2x2 Array Antenna Design:

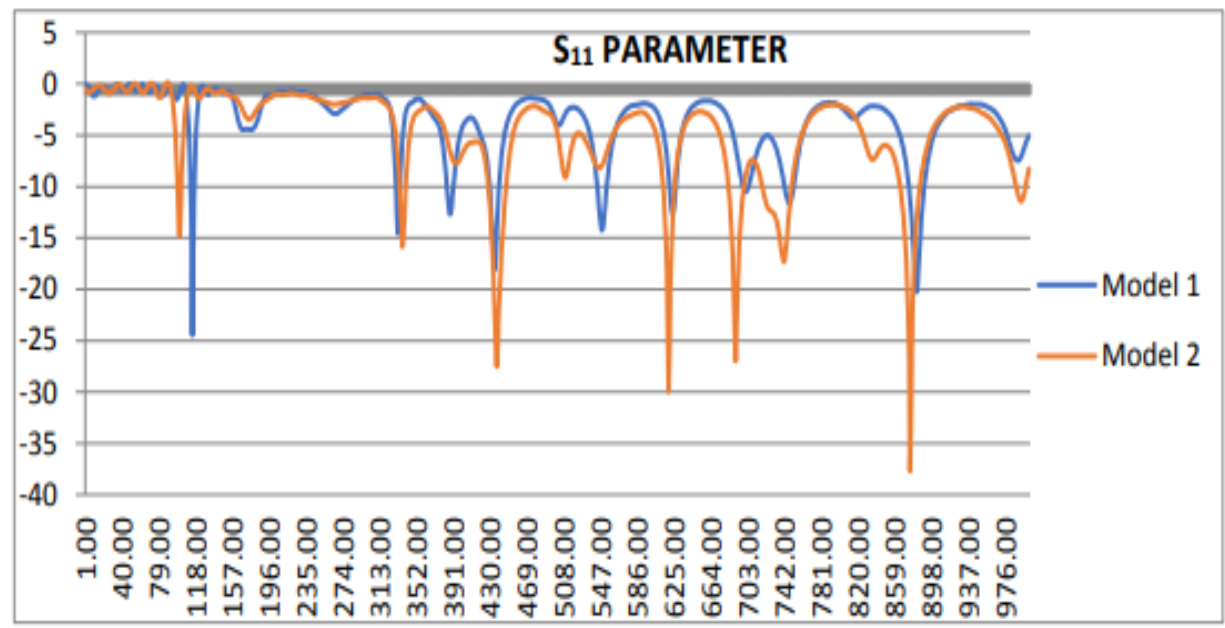

Figure 7. Model 1 and 2 width feeding stripline varians

$\left(\mathrm{S}_{11}\right.$ Parameter Simulation)

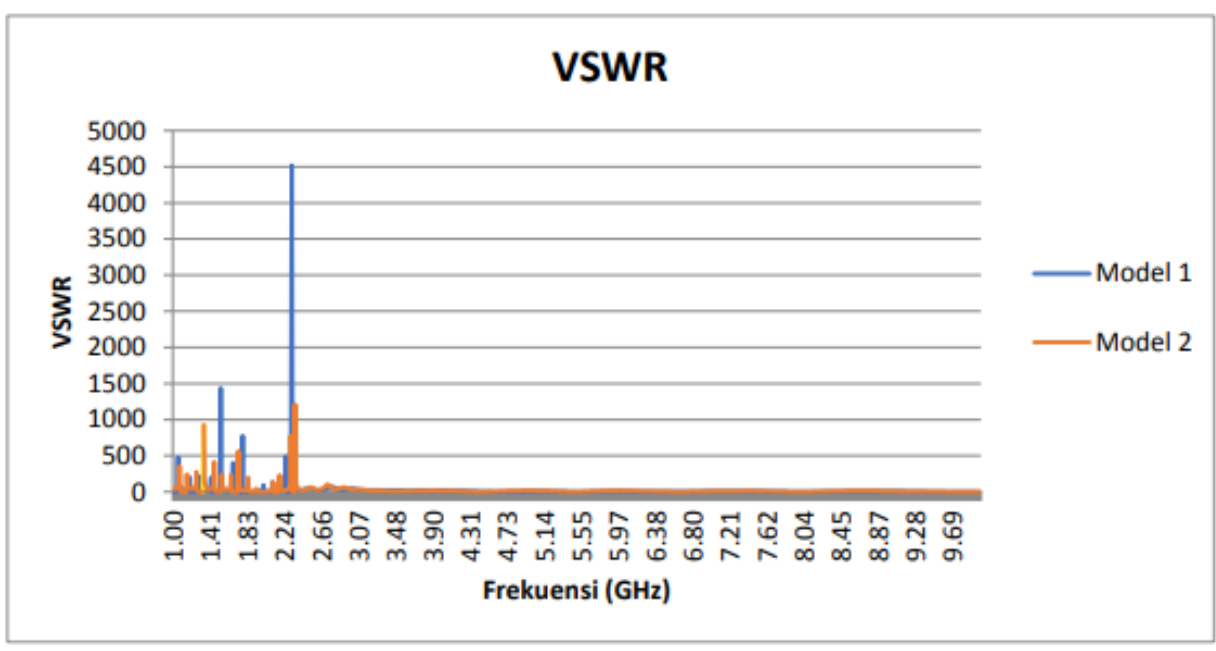

Figure 8. Model 1 and 2 width feeding stripline varians (VSWR Parameter Simulation) 
International Journal of Wireless \& Mobile Networks (IJWMN) Vol. 11, No.2, April 2019

Farfield Directivity Theta Phase (Phi=90)

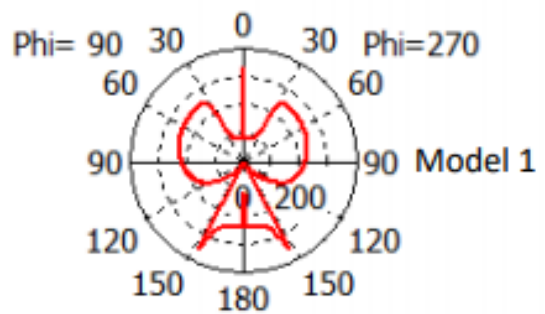

Theta / Degree vs. deg.
Farfield Directivity Theta Phase (Phi $=90$ )

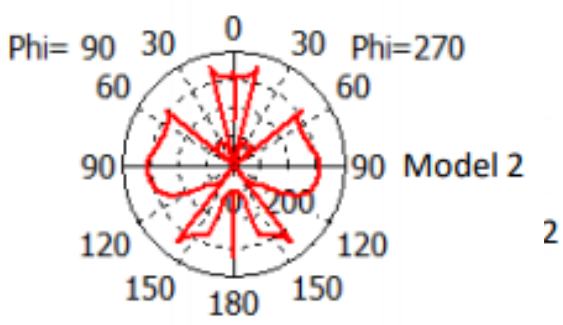

Theta / Degree vs. deg.

Figure 9. Model 1 and 2 width feeding stripline varians (Radiation Pattern Parameter Simulation)

The result indicate that the Curved Microstripline 2x2 Array Antenna Design work in multi band frequency $(\mathrm{f}=2 \mathrm{GHz}, \mathrm{f}=4.5 \mathrm{GHz}, \mathrm{f}=5.5 \mathrm{GHz}, \mathrm{f}=8 \mathrm{GHz}, \mathrm{f}=9.8 \mathrm{GHz})$ with approximately VSWR $\leq 2$, Return Loss $\leq-10 \mathrm{~dB}$ and $5.27 \mathrm{~dB}$ Gain in Omnidirectional radiation pattern.

The simulation result of Curved Microstripline 2x4 Array Antenna Design:

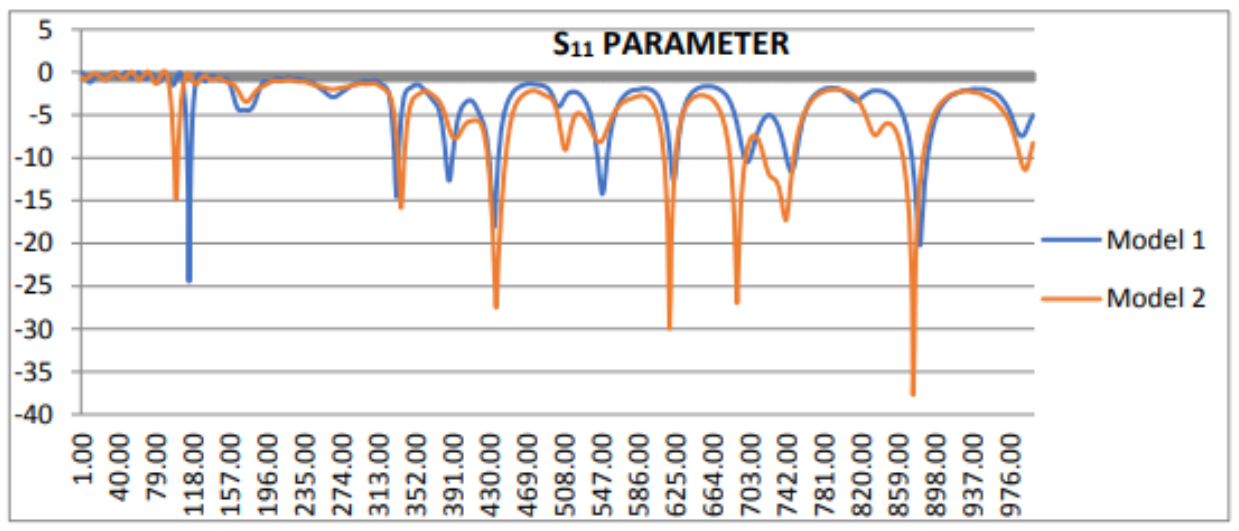

Figure 10. Model 1 and 2 width feeding stripline varians $\left(S_{11}\right.$ Parameter Simulation)

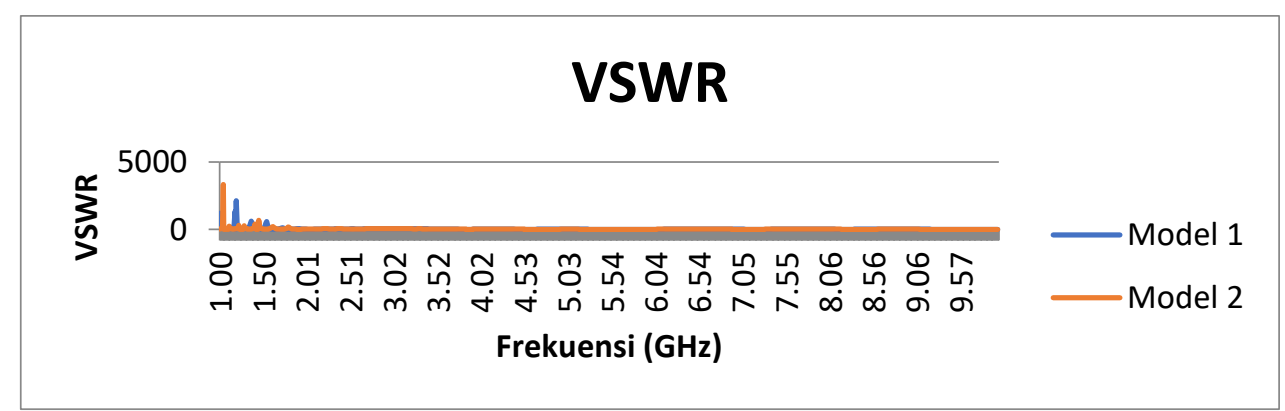

Figure 11. Model 1 and 2 width feeding stripline varians(VSWR Parameter Simulation) 
International Journal of Wireless \& Mobile Networks (IJWMN) Vol. 11, No.2, April 2019

Farfield Directivity Theta Phase (Phi $=90)$

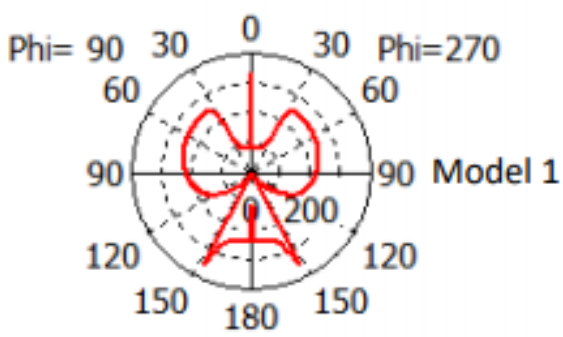

Theta / Degree vs. deg.
Farfield Directivity Theta Phase (Phi=90)

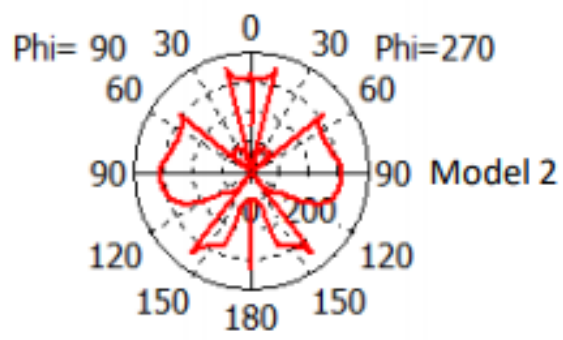

Theta / Degree vs. deg.

Figure 12. Model 1 and 2 width feeding stripline varians (Radiation Pattern Parameter Simulation)

The result indicate that the Curved Microstripline 2x4 Array Antenna Design work in multi band frequency $(\mathrm{f}=4.6 \mathrm{GHz}, \mathrm{f}=5.4 \mathrm{GHz}, \mathrm{f}=7.2 \mathrm{GHz}, \mathrm{f}=9.8 \mathrm{GHz})$ with approximately $\mathrm{VSWR} \leq 2$, Return Loss $\leq-10 \mathrm{~dB}$ and $4.50 \mathrm{~dB}$ Gain in Omnidirectional radiation pattern.

The simulation result of Curved Microstripline 4x4 Array Antenna Design:

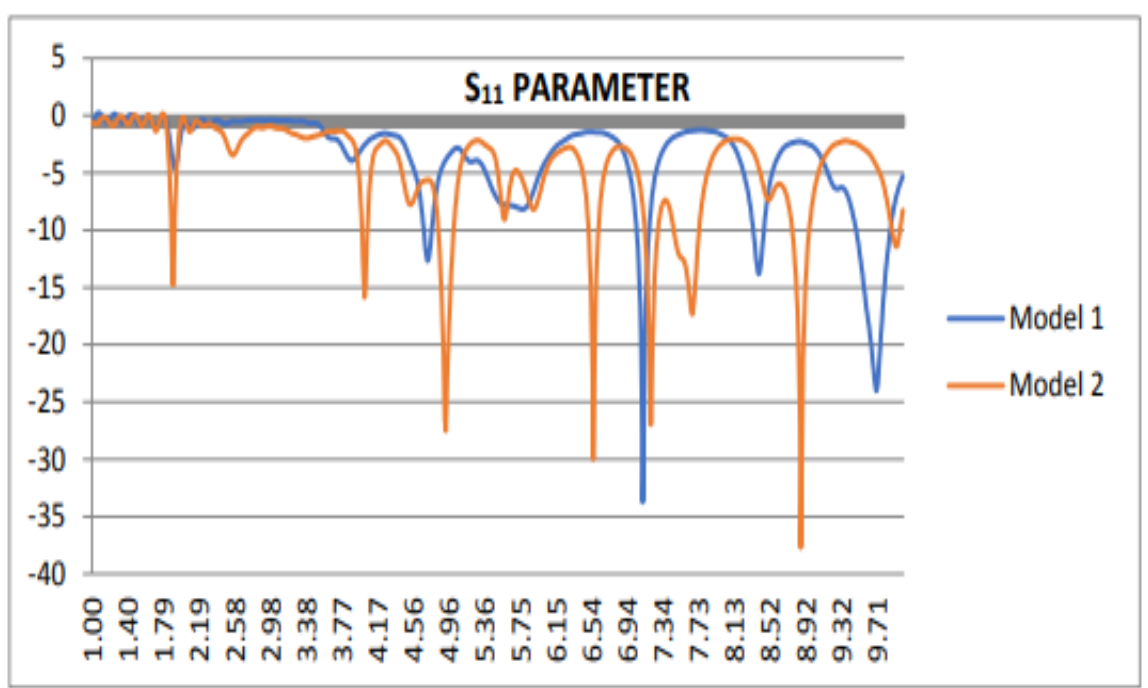

Figure 13. Model 1 and 2 width feeding stripline varians ( $\mathrm{S}_{11}$ Parameter Simulation) 


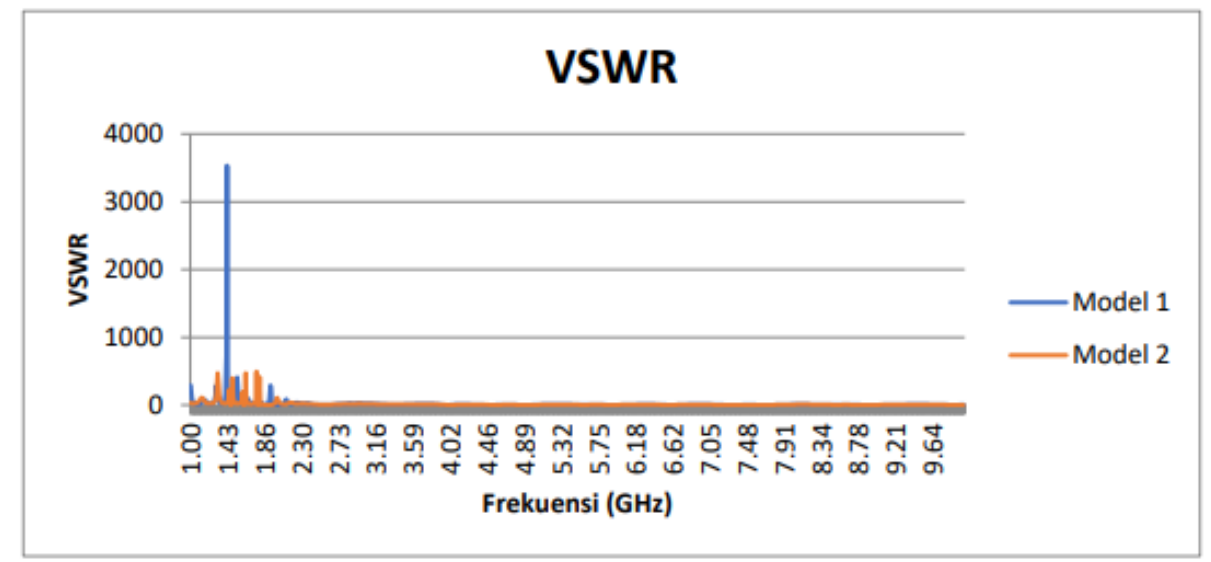

Figure 14. Model 1 and 2 width feeding stripline varians (VSWR Parameter Simulation)

\section{Farfield Directivity Theta Phase (Phi=c Farfield Directivity Theta Phase (Phi=90)}

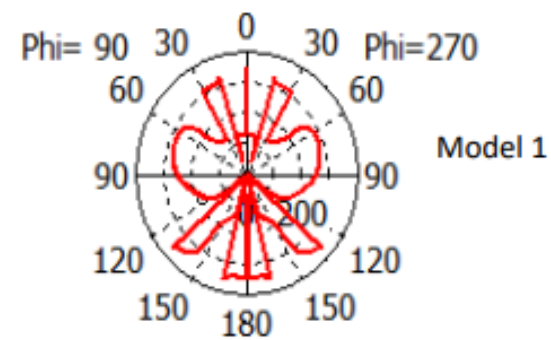

Theta / Degree vs. deg.

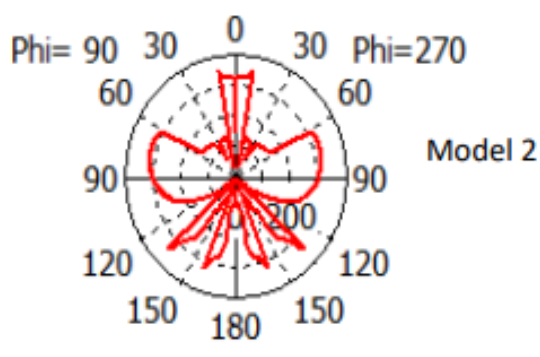

Theta / Degree vs. deg.

Figure 15. Model 1 and 2 width feeding stripline varians (Radiation Pattern Parameter Simulation)

The result indicate that the Curved Microstripline 4x4 Array Antenna Design work in multi band frequency $(\mathrm{f}=2.0 \mathrm{GHz}, \mathrm{f}=3.9 \mathrm{GHz}, \mathrm{f}=4.5 \mathrm{GHz}, \mathrm{f}=4.9 \mathrm{GHz}, \mathrm{f}=5.8 \mathrm{GHz}, \mathrm{f}=6.6 \mathrm{GHz}, \mathrm{f}=7.7 \mathrm{GHz}$, $\mathrm{f}=8.9 \mathrm{GHz}$ ) with approximately VSWR $\leq 2$, Return Loss $\leq-10 \mathrm{~dB}$ and $6.14 \mathrm{~dB}$ Gain in Omnidirectional radiation pattern.

\section{Conclusion}

Width feeding stripline optimise of Curved Microstripline Array Varians Antenna in multiband frequency for radar communications has been presented in this paper. In general, the result was indicate that Curved Microstripline Array Varians Antenna design work in multiband frequency and its can be operated in radar communication application recently. The satisfy indicator parameter characteristic are obtain in term of reflection coeficient, voltage standing wave ratio, return loss, axial ratio and radiation pattern. But, the gain in this antenna still small less than 10dB. This gain result influenced by the dimension in stripline feeding and need more analysis increasing the gain. Based on this result, the proposed Curved Microstripline Array Varians Antenna can be implemented in Radar communication systems. 
International Journal of Wireless \& Mobile Networks (IJWMN) Vol. 11, No.2, April 2019

\section{ACKNOWLEDGMENT}

The authors would like to thank the Indonesian Ministry of Research, Technology and Higher Education through LPDP and PKPI (Sandwich-like) scholarships, Center for Environmental Remote Sensing (CEReS), Josaphat Tetuko Sri Sumantyo (JMRSL Chiba University), Promotor Yono Hadi Pramono and Mashuri (Physics Department, ITS Surabaya).

\section{REFERENCES}

[1] Balanis, C.A. Antena Theory Analysis and Design, Second Edition, John Wiley and Sons, NewYork, 1997.

[2] Edward, Terry. Foundation For Microstrip Circuit Design. Knaresborough England, 1991.

[3] Shafai. Microstrip Antena Design Handbook, Profesor University Of Manitoba, Wimmipeg, Canada, 2001.

[4] ]Kraus, John, D. Electromagnetics, Third Edition, McGraw-Hill, New York, 1984.

[5] Hund, E. Microwave Communications, Component and Circuit, McGraw Hill, New York, 1989.

[6] Hadi Pramono,Yono. Prototipe Antenna Bi-Mikrostrip tapered patch Dengan Dua Arah Pola Radiasi Dan Satu Feeding Monopole Beroperasi Pada Freq.2,4 GHz. Prosiding T. Informatika, UPN. Yogyakarta, 2009.

[7] Hidayah, Ifa. Desain dan Fabrikasi Antena Bi-Mikrostrip tapered patch dengan Dua Arah Radiasi dan Satu Feeding Monopole Untuk Komunikasi Wi-fi. Tesis Magister. Institut Tekologi Sepuluh Nopember. Surabaya, 2009.

[8] Risfaula, Erna. Antena Mikrostrip Panel Berisi 5 Larik Dipole dengan Feedline Koaksial Waveguide untuk Komunikasi 2,4 GHz. Program Keahlian Optoelektronika Jurusan fisika FMIPA-ITS: Surabaya, 2011.

[9] S. Gao, Q. Luo, F. Zhu, Circularly Polarized Antenna, John Wiley \& Sons, Ltd, 2014.

[10] S. Murugan, V. Rajamani, "Study of broadband circularly polarised microstrip antenna" Science Engineering and Management Research (ICSEMR), 2014 International Conference on. IEEE, 2014.

[11] Haider Raad, "An UWB Antenna Array for Flexible IoT Wireless System," Progress In Electromagnetics Research, Vol. 162, 109-121, 2018.

[12] Kurniawan Farohaji, Sri Sumantyo, J. T, Gao Steven, Ito Koichi, Edi Santosa C. "Square-shaped feeding truncated circularly polarised slot antenna". IET Microwaves, Antenna \& Propagation Journals. ISSN 1751-8725, 2018.

[13] Edi Santosa C, Sri Sumantyo, J.T, Yam Chua Ming, Urata Katia, Ito Koichi, Gao Steven. "Subarray Design for C-Band Circularly-Polarized Synthetic Aperture Radar Antenna Onboard Airborne," Progress In Electromagnetics Research, Vol. 163, 107-117, 2018.

[14] Xu Mao-Chun, Gao Steven, Wang Yi, Sri Sumantyo, J.T. "Compact Broadband Dual-Sense Circularly Polarized Microstrip Antenna/Array With Enhanced Isolation". IEEE Transactions on Antennas And Propagation, Vol 65, No.12, 2017. 
International Journal of Wireless \& Mobile Networks (IJWMN) Vol. 11, No.2, April 2019

[15] Luo Qi, Gao Steven, Sobhy Mohammed, Sri Sumantyo, J.T, Li Jianzhou, Wei Gao, Xu Jiadong, Wu Changying. "Dual Circularly Polarised Equilateral Triangular Patch Array". IEEE Transactions on Antennas And Propagation, Vol 64, No.6, 2016.

[16] Kumar Dwivedi M, Srivastava Pragati. "Microstrip Patch Array Antenna for X Band Application". Antenna Test and Measurement Society (ATMS India-16), 01-03 Feb, 2016.

\section{Authors}

The author is a lecturer in Physics Departement, Math and Science Faculty, Ganesha University of Education since 2006. He was graduated in IKIP N Singaraja (now as UNDIKSHA) and got his master degree in ITS Surabaya. The subjects he had taught; Basic Physics 1, Basic Physics 2, Calculus 1, Calculus 2, Physics Laboratory 1, Physics Laboratory 2, Mathematical Physics 1, Mathematical Physics 2, Mechanical Physics, Electromagnetic, Optic and Wave, Statistical Physics and Solid Physics in regular class and RKBI (preparing to International Class). The author also advises schools/students in physics olympiads preparation. Besides teaching the author is activelly involved in some researches.

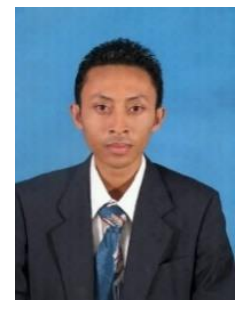
Now, this the author as a doctoral student in Physics Departement, Faculty of Science, ITS Surabaya Indonesia. 